\title{
PERSIAPAN PELAKSANAAN PROGRAM GERAKAN LITERASI SEKOLAH di SEKOLAH MENENGAH ATAS MUHAMMADIYAH 1 BOARDING SCHOOL, di DESA BENTIRING KECAMATAN MUARA BANGKAHULU, BENGKULU
}

\author{
Elyusra \\ Program Studi Pendidikan Bahasa dan Sastra Indonesia \\ FKIP Universitas Muhammadiyah Bengkulu \\ e-mail:elyusra@umb.ac.id
}

\begin{abstract}
ABSTRAK
Mitra dalam kegiatan PKM ini adalah SMA Muhammadiyah 1 Boarding School yang terletak di Kecamatan Muara Bangkahulu, Kota Bengkulu, di Provinsi Bengkulu. Permasalahan yang dihadapi mitra adalah belum mendapatkan informasi yang memadai tentang Gerakan Literasi Sekolah (GLS) sebagai program Kemendikbud yang ditetapkan pada tahun 2015 baik secara konseptual dan prosedural. Untuk mengatasi masalah yang dihadapi mitra, melalui kegitan PKM ini solusi yang akan dilaksanakan adalah melaksanakan kegiatan sosialisasi, pembekalan materi, dan pelatihan. Untuk mewujudkan target luaran di atas, metode yang akan diterapkan mengadopsi pola pelaksanaan penelitian perencanaan tindakan, pelaksanaan tindakan, pengamatan dan evaluasi, serta analisis dan refleksi. Hasil dari kegiatan PKM yang sudah dilaksakana adalah : 1) sudah tersosialisasinya Gerakan Literasi Sekolah (GLS) kepada warga sekolah di SMA Muhammadiyah 1 Boarding School yang terletak di Kecamatan Muara Bangkahulu, Kota Bengkulu. 2) Siswa dan Pembina Asrama sudah memiliki pengetahuan yang baik tentang genre karya fiksi hasil kesusastraan Indonesia, dan 3) siswa sudah memiliki keterampilan menulis laporan kegiatan prabaca dan laporan kegiatan membaca harian.
\end{abstract}

Kata kunci: gerakan literasi sekolah, karya fiksi, kegiatan prabaca, laporan kegiatan membaca, penumbuhan budi pekerti

\section{PENDAHULUAN}

Penumbuhan budi pekerti bagi peserta didik dewasa ini menjadi suatu keharusan. Banyak faktor yang mendorong lahirnya program ini. Selain terkait dengan dekadensi moral yang merebak di kalangan siswa, rendahnya kemampuan literasi siswa, juga didorong oleh peran budi pekerti yang cukup besar dalam kehidupan siswa, baik dalam kehidupan di dalam keluarga, di sekolah, dan di masyarakat. Bahkan, budi pekerti adalah faktor penting yang harus dimiliki kendatipun peserta didik sudah menyelesaikan pendidikannya. Budi pekerti, sikap yang baik, atau perilaku positif, merupakan faktor yang menetukan 
kesuksesan hidup seseorang dewasa ini. Hasil penelitian Thomas J. Stanley, Ph.D. menunjukkan bahwa sepuluh dari seratus faktor yang mempengaruhi kesuksesan seseorang lebih merupakan faktor-faktor sikap, seperti: jujur, disiplin, pandai bergaul, bekerja lebih keras dari yang lain, mencintai hal yang dikerjakan, dan semangat. Forum Ekonomi dunia pun di tahun 2015 mengeluarkan laporan tentang kecakapan yang dibutuhkan dalam menghadapi abad ke-21, yakni literasi, kompetensi, dan karakter (di dalam Antono, 2017)

Dalam Permendikbud RI Nomor 23 Tahun 2015 tentang Penumbuhan Budi Pekerti (selanjutnya disingkat PBP) telah ditetapkan hal-hal sebagai berikut. Pertama, pelaksanaan PBP didasarkan pada nilai-nilai dasar kebangsaan dan kemanusiaan yang meliputi pembiasaan untuk menumbuhkan tujuh hal, yaitu:

"1) internalisasi sikap moral dan spiritual, 2) keteguhan menjaga semangat kebangsaan dan kebhinnekaan untuk merekatkan kesatuan bangsa, 3) interaksi sosial positif antara peserta didik dengan figur orang dewasa di lingkungan sekolah dan rumah, 4) interaksi sosial positif antarpeserta didik, 5) memelihara lingkungan sekolah, 6) penghargaan terhadap keunikan potensi peserta didik untuk dikembangkan, dan 7) penguatan peran orang tua dan unsur masyarakat yang terkait".

Kedua, untuk mengembangkan potensi diri peserta didik secara utuh, sekolah hendaknya memfasilitasi secara optimal. Ketiga, satu diantara kegiatan wajib yang harus dilakukan di sekolah adalah: "1) Menggunakan 15 menit sebelum hari pembelajaran untuk membaca buku selain buku mata pelajaran (setiap hari)".

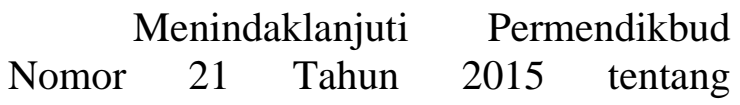

Penumbuhan Budi Pekerti di atas, Menteri Pendidikan dan Kebudayaan (Mendikbud) Anies Baswedan meluncurkan Gerakan Literasi Sekolah (GLS), dengan tajuk "Bahasa Penumbuh Budi Pekerti" Lebih lanjut, Kepala Badan Pengembangan dan Pembinaan Bahasa Kemendikbud, Mahsun, mengatakan Gerakan Literasi Sekolah ini bertujuan membiasakan dan memotivasi siswa untuk mau membaca dan menulis guna menumbuhkan budi pekerti. Dalam jangka panjang, diharapkan dapat dicapai anak-anak yang memiliki kemampuan litarasi tinggi. Dijelaskan lebih lanjut bahwa: "Kegiatan literasi ini tidak hanya membaca, tetapi juga dilengkapi dengan kegiatan menulis yang harus dilandasi dengan keterampilan atau kiat untuk mengubah, meringkas, memodifikasi, menceritakan kembali, dan seterusnya," (http://www.jpnn.com /news/ lima-provinsi-jadi-percontohan-gerakanliterasi-sekolah). Gerakan Literasi Sekolah adalah "Sebuah upaya yang dilakukan secara menyeluruh dan berkelanjutan untuk menjadikan sekolah sebagai organisasi pembelajaran yang warganya literat sepanjang hayat melalui pelibatan publik." (Kemendikbud, tt: 3 ).

$\begin{array}{rrr}\text { Pada } & \text { Struktur } & \text { implementasi } \\ \text { Pemangku } & \text { kepentingan } & \text { GLS, pada } \\ \text { Pendidikan } & \text { Menengah } & \text { mencakup }\end{array}$
Kemendikbud, Dinas Pendidikan Provinsi, Dinas Pendidikan kabupaten/Kota, satuan pendidikan menengah, masyarakat dan LPMP. Dalam Desain Induk GLS dijelaskan:

"GLS adalah gerakan sosial dengan dukungan kolaboratif berbagai elemen.... GLS merupakan suatu usaha atau kegiatan yang bersifat partisipatif dengan melibatkan warga sekolah (peserta didik, guru, kepala sekolah, tenaga kependidikan, pengawas sekolah, Komite Sekolah, orang tua/wali murid peserta didik), akademisi, penerbit, media massa, masyarakat (tokoh masyarakat yang dapat merepresentasikan keteladanan, dunia 
usaha, dll.) dan pemangku kepentingan di bawah koordinasi Direktorat Jenderal Pendidikan Dasar dan Menengah Kementerian Pendidikan dan Kebudayaan (Dirjen Pendasmen, 2016: 7).

Penjelasan lebih lanjut tentang literasi dikemukakan dalam Pedoman Mata Pelajaran SMA/MA/SMK/MAK, mata pelajaran Bahasa Indonesia, bahwa : ... "Dalam satu tahun pelajaran peserta didik dimotivasi agar dapat membaca paling sedikit enam buku (tiga buku sastra dan tiga buku nonsastra) sebagai pengayaan (pengetahuan dan keterampilan) sehingga setelah peserta didik menyelesaikan pendidikan pada jenjang SMA/MA/SMK/MAK telah membaca sekurang-kurangnya 18 judul buku."

Dari paparan di atas dapat dipahami, bahwa Program Penumbuhan Budi Pekerti dan Gerakan Literasi Sekolah sudah berlangsung selama tiga tahun. Mengingat arti penting dari program tersebut berbagai upaya dilakukan pemerintah. Upaya-upaya yang sudah dilakukan seperti mengadakan panduan GLS, membuat desain induk GLS, menyelenggarakan semiloka, dan sebagainya. Banyak pihak berlomba-lomba untuk melaksanakannya. Satuan pendidikan pada berbagai tingkat, komunitas-komunitas di masyarakat di berbagai daerah sudah mengimplementasikannya, termasuk di Provinsi Bengkulu.

\section{Beberapa sekolah di Provinsi} Bengkulu sudah melaksanakan kegiatan pembiasaan membaca sebagai bagian kegiatan GLS. Berdasarkan Informasi lisan yang penulis peroleh dari menghadiri kegiatan sosialisasi GLS bagi siswa, orang tua, sekolah imbas, dan eksternal serta tokoh masyarakat, di SMA Negeri 5 Kota Bengkulu pada 10 November 2016, bahwa tahun 2016 SMAN 5 mendapatkan bantuan pemerintah sebagai sekolah percontohan GLS. Sekolah yang terpilih sebagai sekolah imbas adalah SMA Negeri 2 Kota Bengkulu, SMA Negeri 6 Kota Bengkulu, SMA Muhammadiyah 4 Kota Bengkulu, dan SMA Karolus Kota Bengkulu. Selain informasi di atas, dilaporkan pula bahwa SMAN 5 Kota Bengkulu sudah memenuhi berbagai kriteria pada Tahap Pembiasaan serta melaksanakan beberapa kriteria pada Tahap Pengembangan, seperti melaksanakan Lomba Literasi berupa Lomba Perpustakaan Kelas, Lomba Menulis Karya Sastra, Festival Literasi, dan Penerbitan buku kumpulan cerpen (SMAN 5 Kota Bengkulu, 2016: 7-14). Selain itu, SMPN 1 Kota Bengkulu berhasil memenangkan Lomba Literasi di Tingkat Nasional, dengan menduduki juara satu (https://www.youtube.com). Sekolah Menengah Atas Negeri 1 Bengkulu Selatan pun sudah lama melaksanakan kegiatan membaca serentak selama 15 menit untuk membudayakan membaca (http://beritadelapan.com).

Informasi yang penulis peroleh dari beberapa orang guru di SMA Muhammadiyah 1 Boarding School Kota Bengkulu bahwa GLS diimplementasikan dengan membaca Al Quran sebelum hari pembelajaran dimulai. Dari hasil pengamatan juga diketahui bahwa warga sekolah sudah melalukan kegiatan GLS dengan membaca buku-buku yang berkaitan dengan keislaman dan kemuhammadiyahan dan surat kabar daerah, sebagaimana ditemukan pada ruang tamu dan ruang piket sekolah. Kegiatan membaca buku-buku berupa buku informasi dengan topik yang lain dan buku-buku karya fiksi belum dilakukan.

Berdasarkan interaksi penulis dengan warga sekolah, dapat penulis sampaikan bahwa warga sekolah memiliki minat yang baik untuk melaksanakan GLS. Hal ini dinyatakan dalam bentuk respon yang baik terhadap kehadiran penulis serta memberikan kesempatan kepada penulis menjadi narasumber untuk melaksanakan 
kegiatan persiapan pelaksanaan GLS di sekolah tersebut.

Berdasarkan hasil analisis situasi yang telah dilakukan sebagaimana paparan di atas, dapat penulis nyatakan beberapa permasalahan yang dihadapi mitra. Pertama, secara umum kepala sekolah, guru, tenaga kependidikan, dalam hal ini ketua unit perpustakaan sudah mengetahui informasi tentang GLS. Akan tetapi, informasi dimaksud belum memadai untuk implementasi GLS. Kedua, Aktivitas literasi, yakni berupa kegiatan membaca buku nonmata pelajaran sudah dilaksanakan di SMA Muhammmadiyah 1 Boarding School Kota Bengkulu, dengan membaca buku-buku yang berhubungan dengan keislaman dan kemuhammadiyahan. Akan tetapi, kegiatan membaca buku-buku nonmata pelajaran yang lain dan buku jenis fiksi belum dilaksanakan. Ketiga, kegiatan membaca 15 menit sebelum jam pembelajaran setiap hari sudah dilaksanakan dalam bentuk melaksanakan kegiatan mengaji atau membaca Al Quran serta mengkomunikasikan hafalan $\mathrm{Al}$ Quran oleh siswa kepada guru. Akan tetapi, siswa belum membaca buku-buku nonmata pelajaran dengan topik-topik yang lain dan belum pula membaca buku fiksi hasil kesusastraan Indonesia. Padahal kedua jenis buku ini adalah wajib dibaca siswa dalam implementasi GLS. Keempat, kegiatan membaca buku-buku nonmata pelajaran yang sudah dilakukan oleh guru belum ditulis dalam jurnal kegiatan membaca. Siswa belum secara eksplisit melakukan kegiatan membaca buku nonmata pelajaran, khususnya buku fiksi. dan siswa belum mempunyai jurnal kegiatan membaca. Padahal dalam mata pelajaran Bahasa Indonesia, siswa kelas X sudah berada pada tingkatan/ tahapan Pengembangan (Kemendikbud, 2017a:1-6 dan Kemendikbud, 2017a:1-6).

Dengan demikian, perlu adanya
suatu upaya agar GLS di SMA

Muhammadiyah 1 Boarding School kota Bengkulu dapat terlaksana dengan baik. Satu upaya adalah dengan melakukan kegiatan sosialisasi, pembekalan materi, dan pelatihan. Melalui kegiatan sosialisasi, informasi tentang GLS dapat diketahui oleh seluruh warga sekolah dan persamaan pemahaman pun dapat dicapai. Selain itu, siswa pun perlu diberi pembekalan pengetahuan tentang pelaksanaan GLS, terutama materi yang berkaitan dengan ragam karya fiksi kesusastraan Indonesia dan cara menulis laporan kegiatan membaca.

Target kegiatan pengabdian kepada masyarakat ini mencakup tiga hal, yaitu: 1) Gerakan Literasi Sekolah (GLS) sebagai program Kemendikbud tersosialisasi kepada warga sekolah di SMA Muhammadiyah 1 Boarding School kota Bengkulu, yakni siswa, guru, dan pembina asrama; 2) Siswa, guru, dan pembina asrama memiliki pengetahuan yang mencukupi tentang buku nonmata pelajaran yang termasuk jenis buku fiksi hasil kesusastraan Indonesia, 3) Siswa memiliki keterampilan yang cukup dalam menulis laporan kegiatan membaca sebagai aktivitas implementasi GLS.

\section{METODE KEGIATAN}

Kegiatan persiapan pelaksanaan GLS di SMA Muhammadiyah 1 Boarding School Kota Bengkulu dilaksanakan selama tiga kali pertemuan. Kegiatan atau materi yang diberikan adalah:

Sosialisasi Program Gerakan Literasi Sekolah, 2) Mengenal Buku Fiksi Kesusastraan Indonesia, 3) Pelatihan Menulis Laporan Kegiatan Membaca Buku Fiksi. Waktu pelaksanaan kegiatan 15 Desember s.d. 17 Desember 2018 bertempat di SMA Muhammadiyah 1 Boarding School Kota Bengkulu. 


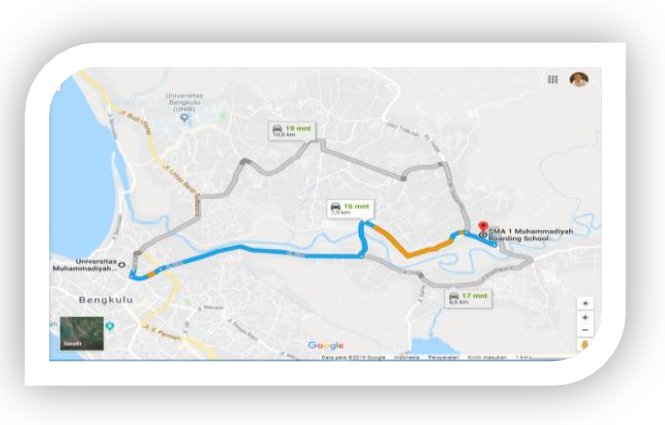

Gambar 1: Lokasi Kegiatan dan Lokasi UMB

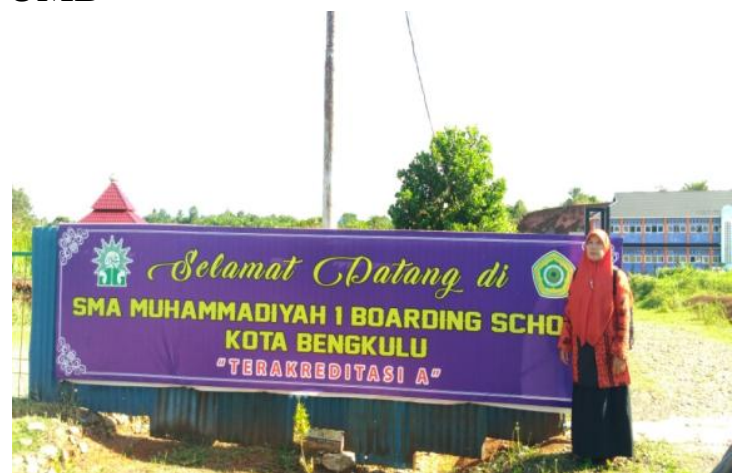

Gambar 2: Penulis di Depan Lokasi Kegiatan

Metode yang akan diterapkan dalam kegiatan PKM ini mengadopsi pola pelaksanaan penelitian tindakan yang meliputi empat tahapan, yaitu: perencanaan tindakan, pelaksanaan tindakan, pengamatan dan evaluasi, serta analisis dan refleksi (Muslich, 2009:40). Tahap perencanaan berupa analisis kebutuhan, penyiapan materi/ bahan ajar, penyusunan jadwal, rencana pelaksanaan, rencana observasi dan evaluasi, serta rencana refleksi. Tahap perencanaan dilakukan berdasarkan hasil analisis kebutuhan. Tahap pelaksanaan merupakan kegiatan mengatasi permasalahan mitra berupa pemaparan materi dan pemberian tugas. Pelaksanaan kegiatan dengan prinsip tidak mengganggu aktivitas atau program-program di sekolah yang sudah terlebih dahulu direncanakan, serta memperhatikan kesiapan tim pelaksana, siswa, sarana, dan prasarana. Tahap pengamatan dilaksanakan sepanjang kegiatan berlangsung ditujukan untuk memperoleh informasi tentang keterlaksaan program. Kegiatan evaluasi dilakukan terhadap berbagai bahan, sumber daya yang mendukung, dan kinerja peserta kegiatan. Tahap analisis dilakukann terhadap hasil pengamatan dan refleksi dilakukan dengan meninjau dan memikirkan kembali kegiatan yang sudah dilakukan, baik yang bersifat material, maupun yang bersifat sumber daya manusia. Langkah evaluasi dilaksanakan dengan observasi dan wawancara dengan warga sekolah yang berpartisipasi. Prosedur kegiatan tersebut dituangkan dalam bagan berikut :

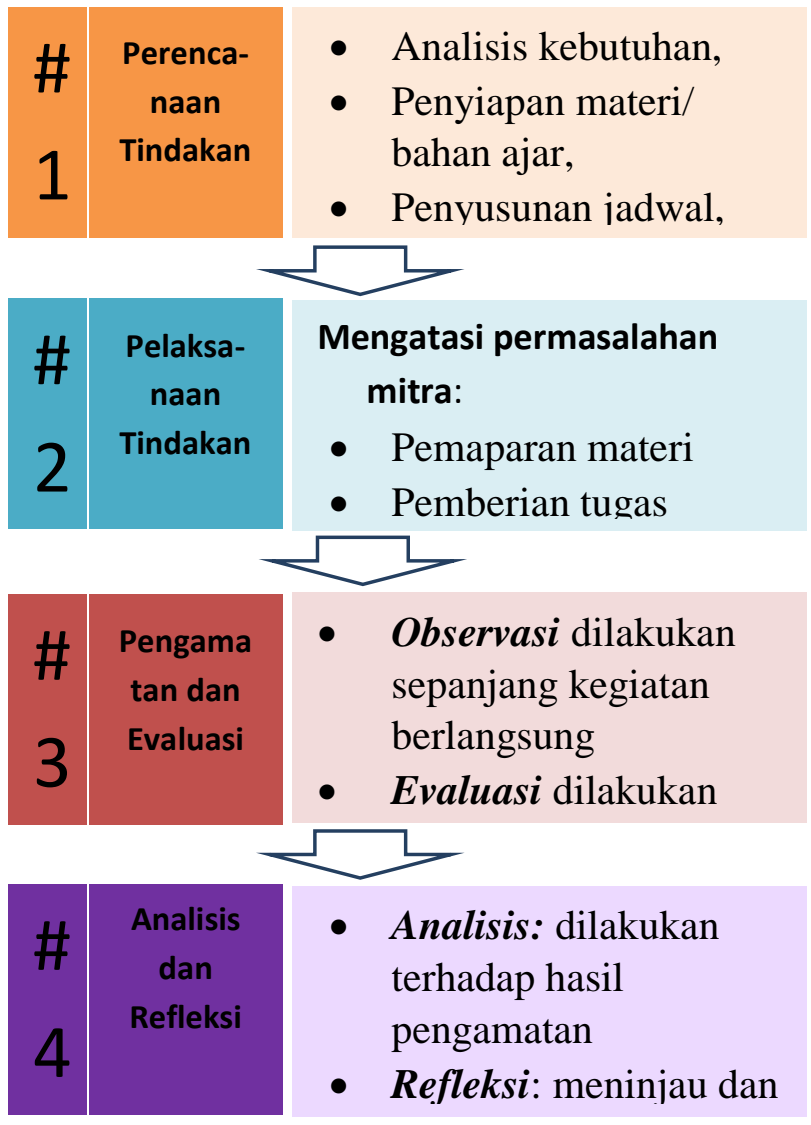

\section{Gambar 3: Langkah-langkah Kegiatan}

\section{HASIL DAN PEMBAHASAN}

Hasil yang dicapai dalam kegiatan PKM ini mencakup hasil yang diperoleh pada berbagai tahapan pelaksanaan solusi permasalahan mitra. Hasil-hasil dimaksud dipaparkan dalam bagian berikut.

\subsection{Peta Bahan Ajar Persiapan Pelaksanaan Program GLS}


Berdasarkan hasil analisis kebutuhan, mitra membutuhkan tiga topik materi, yaitu : 1) sosialisasi program gerakan literasi sekolah, 2) mengenal buku fiksi kesusastraan indonesia, dan 3) pelatihan menulis laporan kegiatan membaca buku fiksi. Peta Pembelajaran ketiga materi tersebut adalah :

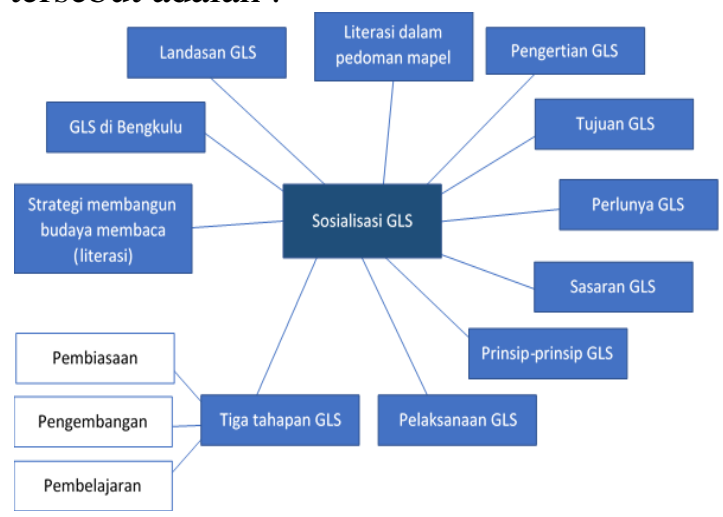

Gambar 4: Peta Bahan Ajar

"Sosialisasi GLS"

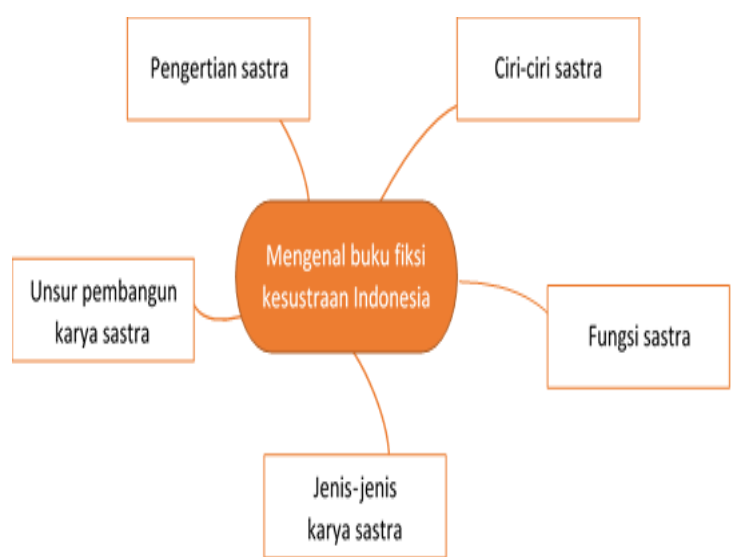
Gambar 5: Peta Bahan Ajar "Mengenal Buku Fiksi Kesusastraan Indonesia"

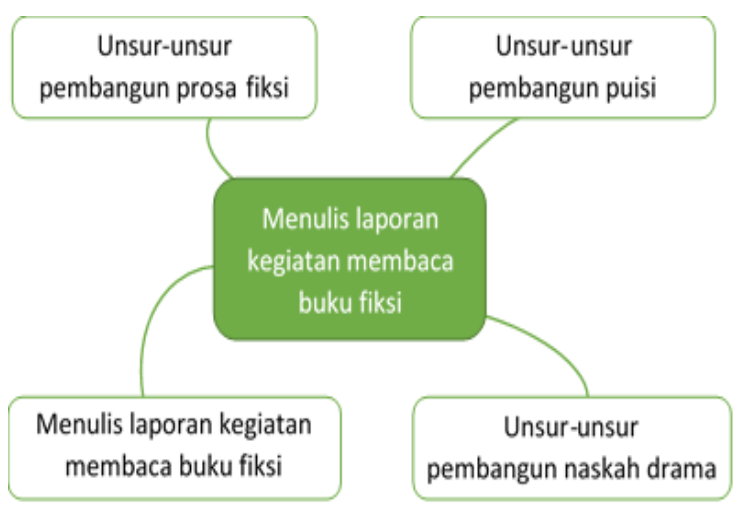

Gambar 6: Peta Bahan Ajar "Menulis Laporan Kegiatan Membaca Buku Fiksi”

Diharapkan dengan peta bahan ajar tersebut dapat disusun materi paparan tiga kegiatan yang akan dilaksanakan, baik yang berupa sosialisasi, pembekalan pengetahuan, dan pembekalan keterampilan. Pembuatan peta pembelajaran merupakan suatu tahapan yang penting dalam prosedur pengembangan bahan ajar. Dinyatakan bahwa peta kebutuhan bahan ajar ditujukan untuk mengetahui ruang lingkup materi dan urutannya (Depdiknas, 2008:17).

\subsection{Bahan Ajar Kegiatan Persiapan Pelaksanaan GLS}

Berdasarkan peta bahan ajar di atas disusun bahan ajar berbentuk hand out dengan tiga topik sebagaimana yang dikemukakan di atas. Selain materi paparan juga dipersiapkan juga format jurnal kegiatan prabaca dan format jurnal laporan harian membaca. Beberapa cuplikan materi yang dipaparkan pada topik "Sosialisasi GLS" adalah sebagai berikut: 


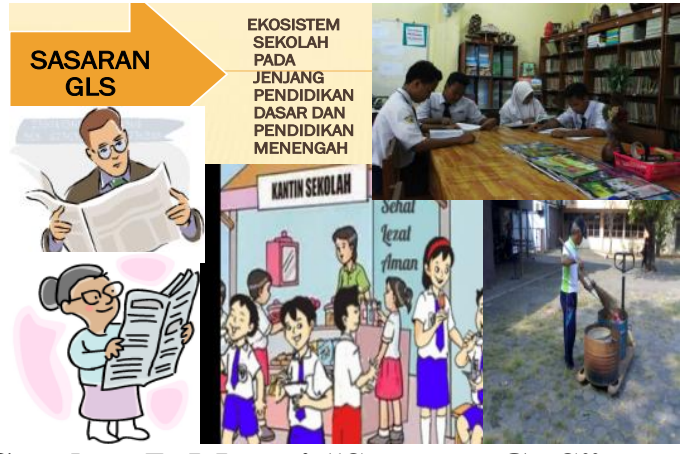

Gambar 7: Materi "Sasaran GLS"

Dari ilustrasi di atas dapat diketahui bahwa semua warga sekolah merupakan partisipan kegiatan GLS. Warga sekolah seperti siswa, guru, petugas kebersihan sekolah, pemilik kantin sekolah, pembina asrama, tukang kebun adalah pelaku dalam GLS. Selain melakukan kegiatan membaca juga menulis. Misalnya, pemilik kantin sekolah menulis dan memajang teks poster makanan sehat di dinding kantin, daftar menu dan harganya.

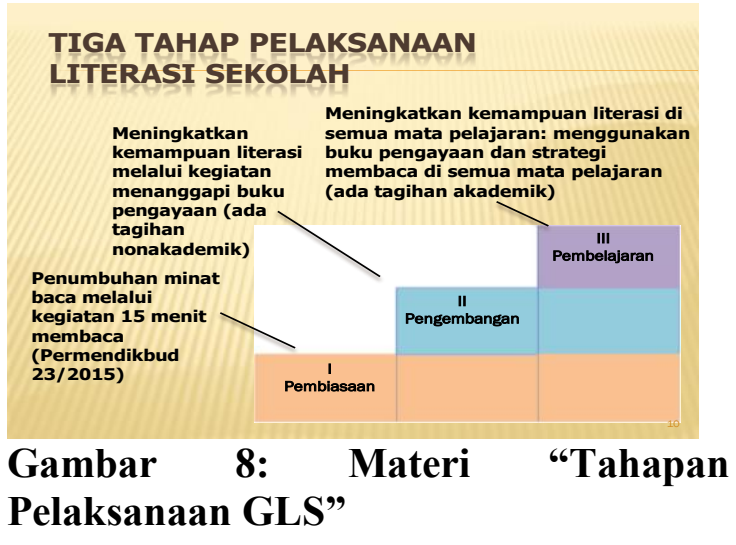

Pada topik materi " Mengenal Buku Fiksi Kesusastraan Indonesia" diberikan materi unruk memotivasi siswa membaca buku fiksi, berupa fungsi atau manfaat karya sastra, serta aneka ragam karya sastra yang dapat menjadi bahan bacaan pilihan siswa. Di antara materi paparan tersebut adalah:

\section{FUNGSIS, \\ 1. Horace (da dulce et utile \\ 2. Menurut Rs \\ Warren (19}

a. Sebagai hiburan

b. Sebagai renungan

c. Sebagai bahasan pelajaran

d. Sebagai media komunikasi simbolik

e. Sebagai pembuka paradigma berpikir

\section{Gambar 9: Materi "Fungsi Sastra"}

\author{
C. FUNGSI SASTRA DALAM MASYARAKAT \\ Kreatif \\ Didaktis \\ Estetis \\ Moralitas \\ Religius \\ Dapat dijadikan bahan perbandingan/ \\ penelitian \\ Memperkaya pengetahuan \\ (Rohmansyah, 2014:8)
}

\section{Gambar 10: Materi "Fungsi Sastra"}

\section{Gambar 11: Materi “ Karya Fiksi \\ Kesusastraan Indonesia"}

Dari paparan materi di atas terlihat jelas bahwa orientasi buku bacaan siswa adalah buku fiksi hasil kesusastraan Indonesia. Hal ini dilatarbelakangi oleh hasil observasi awal terhadap kegiatan literasi yang sudah berlangsung di SMA Muhammadiyah 1 Boarding School Kota Bengkulu, yakni literasi membaca buku nonfiksi sudah berlangsung dengan cukup baik. Warga sekolah sudah aktif membaca buku-buku dengan topik keislaman dan kemuhammadiyahan. Kegiatan literasi dengan membaca dua jenis buku ini, yakni buku sastra ragam fiksi dan buku-buku agama, merupakan suatu upaya yang strategis untuk mewujudkan pendidikan yang berhasil dengan kualitas yang baik. Dikemukakan oleh Jim Trelease, seorang 
jurnalis dan pakar pendidikan dari Amerika serikat, bahwa buku hasil kesusastraan (buku fiksi) menyuguhkan arti kehidupan manusia yang merupakan tujuan sejati dari semua pendidikan dan menempatkan siswa dalam situasi yang paling dekat dengan hati manusia. Buku keagamaan dapat memberikan arti kehidupan yang jelas (di dalam Antono, 2017:36). Peranan atau pentingnya membaca buku fiksi dinyatakan pula: "kemampuan literasi adalah kemampuan berbaca- tulis dan malah bagi sebagian orang literasi berkonotasi dengan kompetensi sastra" bahkan salah satu tujuan pendidikan yang penting diwujudkan adalah memproduksi manusia terdidik dan menunjukkan apresiasi terhadap sastra (Alwasilah, 2012:177).

\section{3 Kompetensi Peserta, Siswa}

Topik materi "Sosialisasi Program Gerakan Literasi Sekolah" dilaksanakan dengan menyampaikan paparan yang bersifat memberikan pengetahuan tentang GLS sebagai suatu program Kemendikbud yang merupakan tindak lanjut dari Permendikbud RI Nomor 23 Tahun 2015 tentang Penumbuhan Budi Pekerti. Permendikbud ini diterbitkan sebagai respon terhadap keresahan masyarakat terhadap dekadensi moral di kalangan generasi muda.

Dalam pemaparan diberikan penekanan bahwa GLS adalah program yang harus dilaksanakan di setiap satuan pendidikan tingkat sekolah dasar dan menengah. Hal ini dengan tujuan menumbuhkan kesadaran bagi warga sekolah untuk berperan serta aktif dalam kegiatan tersebut. Berdasarkan tiga tahap pelaksanaan GLS, maka sudah waktunya SMA Muhammadiyah 1 Boarding School Kota Bengkulu melaksanakannya.

Topik materi "Mengenal Buku Fiksi Kesusastraan Indonesia", pada dasarnya berupa materi pengulangan, karena siswa tingkat SMA sudah mempelajarinya. Jenis buku fiksi yang dibahas mencakup: buku karya puisi, prosa, dan drama. Karya jenis film belum disampaikan, menginat alokasi waktu yang sangat terbatas. Dari hasil pengamatan diketahui bahwa siswa masih belum menguasai materi ini dengan baik. Siswa belum menguasai sepenuhnya konsepkonsep prasyarat/ konsep-konsep pembentuk dalam topik ini. Oleh sebab itu, penjelasan yang bersifat elaboratif diberikan dalam pertemuan tersebut. Untuk meningkatkan pemahaman siswa terhadap materi ini dan untuk mempertahankan retensi, kepada siswa diberi waktu untuk membuat catatancatatan pada hand out yang dibagikan. Hal ini perlu dilakukan, karena materi ini akan diaplikasikan dalam kegiatan membaca nanti serta akan mempengaruhi keberhasilan kegiatan membaca. Pentingnya membekali siswa dengan kemampuan dasar literasi dinyatakan oleh Alwasilah “ ... siswa membangun literasi dengan diajari terlebih dahulu tentang literasi" (2012:177).

Materi dengan topik "Pelatihan Menulis Laporan Kegiatan Membaca Buku Fiksi" dilaksanakan pada hari ketiga, yang pada dasarnya merupakan kegiatan mengaplikasikan materi yang dipelajari pada hari ke dua. Kegiatan- kegiatan pada pertemuan ke-3 ini yaitu: 1) pemaparan materi, 2) kegiatan membaca karya fiksi berupa puisi dan prosa, 3) membuat laporan prabaca, 4) membuat laporan harian membaca. Keempat kegiatan ini dapat dilaksanakan.

Dalam pelaksanaan pelatihan ini, siswa mengikutinya dengan antusias. Dengan penyampaian prosedur pelatihan dan alokasi waktu utntuk setiap tahap kegiatan siswa mampu menyelesaikan tugas-tugas yang diberikan. Siswa juga menyampaikan pertanyaan kepada penulis yang bertindak sebagai narasumber. Beberapa pertanyaan yang dikemukakan siswa seperti: 1) Apakah buku ini fiksi?; 2) kolom pertanyaan/ tanggapan apakah diisi juga?; 3) Apakah pertanyaan yang 
ditulis adalah pertanyaan untuk diri kita atau untuk pengarang? Pertanyaan yang diajukan kepada penulis ini didiskusikan secara klasikal. Siswa dibimbing untuk menjawabnya.

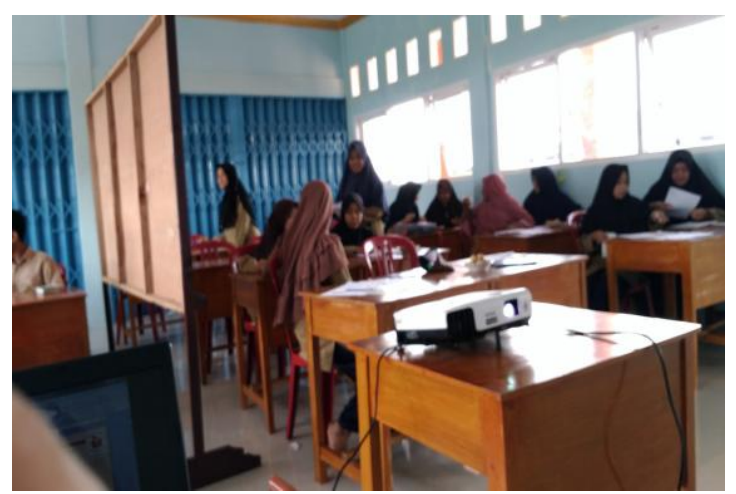

Gambar 13: Siswa Antusias Melakukan Kegiatan Membaca

Dari hasil analisis kinerja siswa dalam menulis laporan membaca dapat disampaikan hasil sebagai berikut.

\section{1) Siswa sudah baik dalam menuliskan identitas buku yang akan dibaca}

Secara umum siswa sudah mampu mengidentifikasi identitas buku yang akan dibaca. Hal ini dimungkinkan oleh panduan yang diberikan, yakni berupa format "Laporan Kegiatan Prabaca" yang dapat langsung diisi siswa. Format dimaksud adalah:

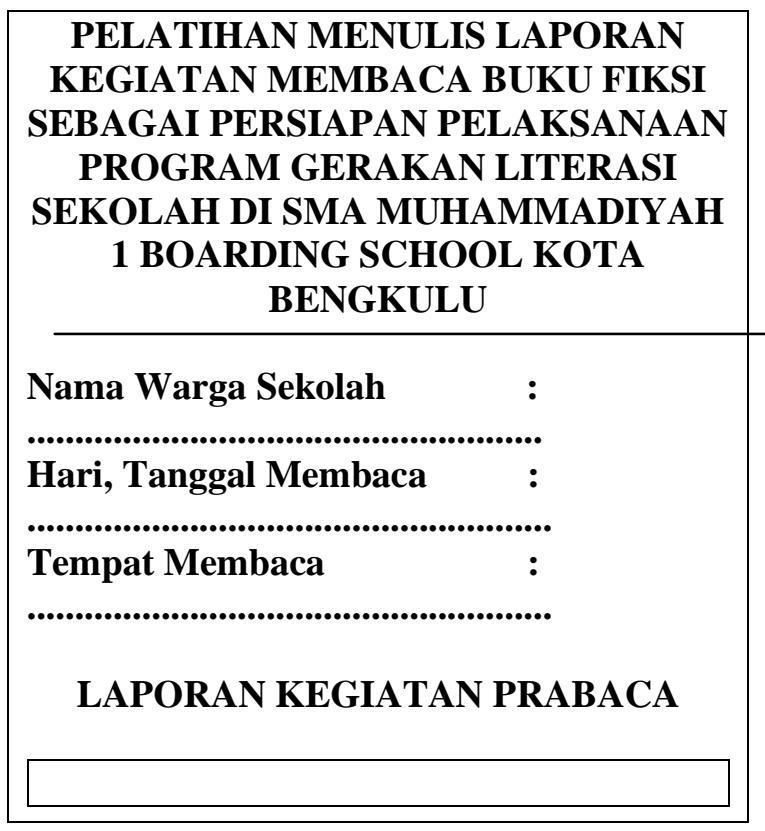

98 www.jurnal.umb.ac.id

\begin{tabular}{ll} 
Judul buku & $:$ \\
Pengarang & $:$ \\
\hline$\ldots \ldots \ldots \ldots \ldots \ldots \ldots \ldots \ldots$ & \\
\hline &
\end{tabular}

Gambar 14: Format "Laporan Kegiatan Prabaca"

Walaupun demikian, masih ada siswa yang ragu dalam mengidentifikasi jenis buku yang dibaca. Data berikut menyatakan siswa ragu mengidentifikasi jenis buku fiksi dan nonfiksi.

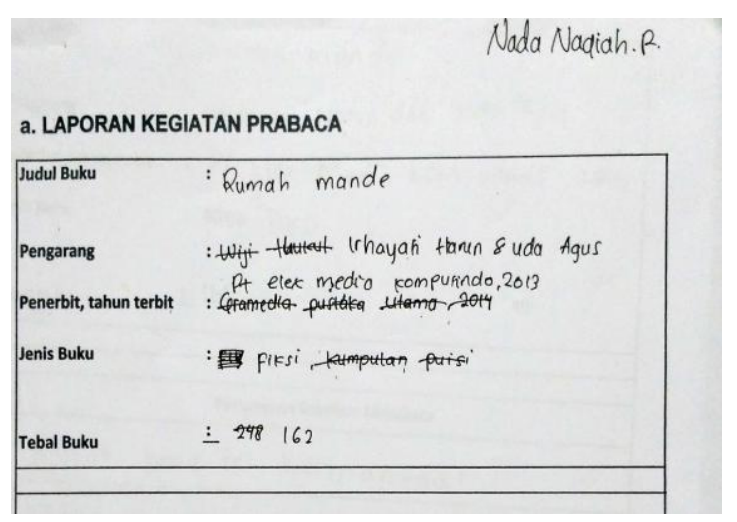

Gambar 15 : Keraguan Siswa dalam mengidentifikasi jenis buku yang dibaca

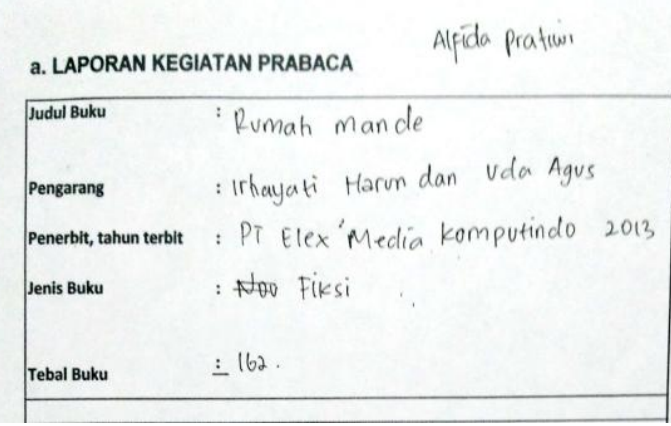


Gambar 16: Keraguan Siswa dalam Mengidentifikasi Jenis Buku yang Dibaca

\section{2) Siswa belum cukup terampil membuat pertanyaan prabaca}

Pada format "Pertanyaan sebelum Membaca" sudah disediakan delapan nomor yang dapat diisi dengan pertanyaan prabaca, seperti gambar berikut:

\begin{tabular}{|c|c|}
\hline No. & Pertanyaan sebelum Membaca \\
\hline 1 & \\
\hline 2 & \\
\hline 3 & \\
\hline 4 & \\
\hline 5 & \\
\hline 6 & \\
\hline 7 & \\
\hline
\end{tabular}

Gambar 17: format Prabaca

Akan tetapi, tidak ada siswa yang membuat delapan pertanyaan prabaca. Jumlah pertanyaan yang dibuat siswa berkisar dua sampai lima pertanyaan. Yang membuat lima pertanyaan pun hanya satu orang siswa. Pertanyaan prabaca yang dibuat siswa tersebut terhadap buku jenis prosa/ novel berjudul Sabtu Bersama Bapak karya Adhitia Mulya adalah:

a) Menceritakan tentang apa?

b) Mengapa harus bersama bapak bukan ibu atau yang lain?

c) Apa tujuan pengarang?

d) Sedih apa bahagia?

e) Mengapa hari sabtu?

Lima pertanyaan yang dibuat siswa di atas dapat dinyakan sebagai pertanyaan yang presentatif, karena sudah mengacu kepada hakikat karya prosa fiksi. Siswa sudah mampu membuat pertanyaan yang berkenaan dengan struktur sebuah novel. Dinyatakan bahwa unsur prosa fiksi mencakup isi, yang terdiri atas tema dan amanat. Selain itu, struktur prosa fiksi yang merupakan cara bercerita pengarang dengan pendekatan, metode, dan teknik dalam membangun cerita, meliputi alur/plot, seting, penokohan, sudut pandang, dan gaya bahasa (Ramadhansyah (2012:151).

Lima pertanyaan di atas jika diidentifikasi lebih lanjut sudah menanyakan hal yang berhubungan dengan fakta-fakta faktual yang akan ditemukannya nanti setelah membaca buku tersebut. Hal ini dikenal dengan struktur intrinsik karya. Dinyatakan bahwa "Unsur Intrinsik (intrinsic) adalah unsur-unsur yang secara langsung terut serta membangun, menyebabkan prosa fiksi hadir sebagai teks sastra, yang secara faktual akan dijumpai seseorang yang membaca karya tersebut, seperti: plot, penokohan, tema, latar, sudut pandang, gaya bahasa (Nurgiyantoro,2015:29-30). Identifikasi lima pertanyaan di atas berdasarkan unsur intrinsik karya prosa fiksi berupa novel seperti berikut:

Tabel: 4 Identifikasi pertanyaan siswa berdasarkan unsur intrinsik buku fiksi

\begin{tabular}{|c|l|l|}
\hline No. & \multicolumn{1}{|c|}{ Pertanyaan Siswa } & \multicolumn{1}{|c|}{$\begin{array}{c}\text { Unsur } \\
\text { Intrinsik } \\
\text { yang } \\
\text { Ditanyakan }\end{array}$} \\
\hline 1 & $\begin{array}{l}\text { Menceritakan tentang } \\
\text { apa? }\end{array}$ & Tema \\
\hline 2 & $\begin{array}{l}\text { Mengapa harus } \\
\text { bersama bapak bukan } \\
\text { ibu atau yang lain? }\end{array}$ & Tokoh \\
\hline 3 & Apa tujuan pengarang? & Amanat \\
\hline 4 & Sedih apa bahagia? & Latar \\
\hline 5 & Mengapa hari sabtu? & Latar \\
\hline
\end{tabular}

Pertanyaan-pertanyaan lain yang dibuat siswa yang sudah baik, seperti:

a) Apa saja kisah-kisah di dalam buku ini?

b) Mengapa judul buku itu Madre?

c) Apakah tokoh pelaku/ pemeran...?

d) Apa saja keistimewaan buku tersebut?

Selain mengajukan pertanyaan prabaca yang berkaitan dengan struktur intrinsik karya fiksi, ada pula siswa yang 
sudah membuat pertanyaan yang berhubungan dengan hal-hal lain yang berada di luar karya. Pertanyaan yang dibuat siswa adalah:

a) Apakah buku itu bisa benar-benar membuat kita meneteskan air mata?

b) Mengapa buku ini diterbitkan?

c) Apakah buku ini bermanfaat?

d) Apakah buku ini bisa membuat yang membacanya bahagia?

Hasil identifikasi terhadap pertanyaan-pertanyaan di atas, dapat dinyatakan bahwa siswa sudah mengajukan pertanyaan yang merupakan faktor luar karya sastra, yang dikenal dengan struktur ekstrinsik. Dinyatakan Wellek \& Warren (di dalam Nurgiyantoro, 2015:29-30) bahwa Unsur Ekstrinsik (extrinsic) merupakan unsur-unsur yang berada di luar teks sastra/ prosa fiksi, tetapi secara tidak langsung mempengaruhi bangun atau sistem organisme teks sastra, seperti pengarang, pembaca, keadaan di lingkungan pengarang, karya seni yang lain. Hasil identifikasi pertanyaan siswa di atas sebagai berikut:

Tabel: 5 Identifikasi pertanyaan siswa berdasarkan unsur ekstrinsik buku fiksi

\begin{tabular}{|c|l|l|}
\hline No. & \multicolumn{1}{|c|}{ Pertanyaan Siswa } & \multicolumn{1}{|c|}{$\begin{array}{c}\text { Unsur } \\
\text { Ekstrinsik } \\
\text { yang } \\
\text { Ditanyakan }\end{array}$} \\
\hline 1 & $\begin{array}{l}\text { Apakah buku itu bisa } \\
\text { benar-benar membuat } \\
\text { kita meneteskan air } \\
\text { mata? }\end{array}$ & Pembaca \\
\hline 2 & $\begin{array}{l}\text { Mengapa buku ini } \\
\text { diterbitkan? }\end{array}$ & Pengarang \\
\hline 3 & $\begin{array}{l}\text { Apakah buku ini } \\
\text { bermanfaat? }\end{array}$ & Pembaca \\
\hline 4 & $\begin{array}{l}\text { Apakah buku ini bisa } \\
\text { membuat yang } \\
\text { membacanya bahagia? }\end{array}$ & Pembaca \\
\hline
\end{tabular}

Selain pertanyaan prabaca yang presentatif tersebut, ditemukan pula pertanyaan yang belum berorientasi kepada hakikat karya fiksi genre novel. Contoh pertanyaan-pertanyaan dimaksud adalah:

a) Mengapa buku ini diterbitkan?

b) Apakah buku ini termasuk kisah nyata?

c) Apa tujuan kita membaca buku ini?

Dari uraian di atas dapat penulis sampaikan beberapa hal. Pertama, pertanyaan prabaca yang dibuat siswa dari segi jumlahnya masih sangat kurang. Maksudnya, belum sebanding dengan jumlah unsur intrinsik karya fiksi yang dapat dipertanyakan. Jika satu struktur intrinsik ditanyakan dengan satu pertanyaan, maka setidaknya ada tujuh pertanyaan yang harus dibuat. Misalnya:

a) Apa permasalahan/ tema yang diangkat pengarang dalam novel ini?

b) Apa saja amanat pengarang?

c) Siapa saja tokoh cerita?

d) Bagaimana alur cerita?

e) Bagaimana latar cerita?

f) Apa jenis sudut pandang yang digunakan pengarang

g) Bagaimana gaya bahasa pengarang?

Dari tujuh pertanyaan minimal di atas yang harus dapat dibuat siswa, pertanyaan yang tidak muncul adalah pertanyaan yang berhubungan dengan unsur amanat, latar, sudut pandang, dan gaya bahasa. Padahal, setiap pertanyaan di atas dapat pula dirinci lebih lanjut. Misalnya pertanyaan untuk unsur latar, dapat dirinci menjadi: 1) Di mana sajakah latar tempat cerita?, 2) Bagaimana latar waktu ?, 3) Bagaimana latar suasana. Sebetulnya, materi yang berhubungan dengan pertanyaan prabaca ini sudah diberikan pada topik yang ke-2, yakni materi tentang unsur-unsur pembangun karya prosa fiksi. Dengan demikian, materi perlu dilengkapi dengan contoh-contoh. Sehubungan dengan pertanyaan yang berhubungan dengan unsur ekstrinsik karya yang sudah muncul pada pertanyaan prabaca yang dibuat siswa, maka materi tentang ini harus diperluas lagi. Sedangkan pertanyaan yang tidak relevan yang dibuat 
siswa, menandakan penguasaan konsep siswa masih kurang. Oleh sebab itu, perlu usaha yang lebih banyak lagi.

Tindak lanjut pembekalan kemampuan prabaca ini sangat penting. Kemampuan membuat pertanyaan sebelum membaca berperanan terhadap keberhasilan membaca. Hasil penelitian Sumarwati, dkk. (2015:74) menyatakan bahwa pembuatan prequestion dalam kegiatan prabaca dapat meningkatkan keaktifan dan motivasi dalam membaca, serta meningkatkan pemahaman.

Tugas menulis laporan harian membaca siswa secara umum juga menunjukkan kualitas yang sama. Pada latihan yang pertama siswa diberi tugas menulis ringkasan karya puisi yang dibaca. Siswa kelihatan bingung untuk menulis ringkasan puisi tersebut. Bahkan ada siswa yang tidak dapat menuliskan ringkasannya. Setelah materi tentang unsur-unsur pembangun puisi dikemukakan kembali, siswa mulai menulis. Bagi siswa yang menulis ringkasan, pada umumnya ringkasan yang ditulis siswa hanya berkenaan dengan permasalahan/ tema puisi saja.

Sama halnya dengan menulis pertanyaan prabaca tadi, dalam menulis ringkasan siswa belum berorientasi pada keseluruhan struktur pembangun puisi. Menurut Waluyo (1987:28), sebuah puisi dibangun dari berbagai unsur yang biasanya disebut sebagai struktur batin dan struktur fisik puisi. Struktur batin puisi terdiri atas unsur: tema, perasaan, nada dan suasana, dan amanat. Struktur fisik puisi, sebagai sarana-sarana penyampai struktur batin tadi mencakup diksi, pengimajian, kata konkrit, bahasa figuratif, versifikasi, dan tipografi. Seharusnya ringkasan yang dibuat siswa berhubungan dengan lima unsur struktur batin tersebut. Pada bagian pertanyaan dan tanggapan siswa dapat membuatnya berdasarkan struktur fisik puisi. Misalnya, pertanyaan tentang makna diksi yang digunakan, tanggapan terhadap majas dan kata konkrit. .

Contoh ringkasan puisi yang ditulis siswa sebagai berikut:

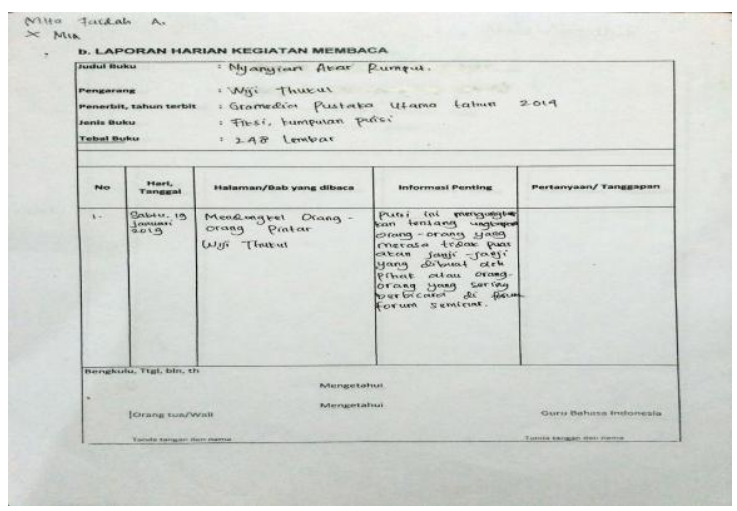

Gambar 18: Ringkasan Puisi yang Ditulis Siswa

\section{PENUTUP}

Berdasarkan hasil pelaksanaan, kegiatan persiapan pelaksanaan program Gerakan Literasi Sekolah di SMA Muhammadiyah Boarding School Kota Bengkulu Tahun Pelajaran 2018/ 2019 dapat diambil kesimpulan sebagai berikut :

1. Sekolah Menengah Atas Muhammadiyah Boarding School Kota Bengkulu sebagai mitra kegiatan PkM ini menghadapi permasalahan dalam persiapan pelaksanaan GLS, berupa belum memperoleh informasi yang memadai tentang GLS.

2. Permasalahan mitra diatasi dengan melakukan sosialisasi, pembelajaran, dan pelatihan.

3. Dari kegiatan PkM ini diperoleh bahan ajar berupa hand out sebanyak tiga topik, dengan judul: 1) Sosialisasi Program Gerakan Literasi Sekolah, 2) Mengenal Buku Fiksi Kesusastraan Indonesia, dan 3) Pelatihan Menulis Laporan Kegiatan Membaca Buku Fiksi. 
4. Program Gerakan Literasi sekolah (GLS) sudah tersosialisasi kepada siswa, guru, dan Pembina Asrama Sekolah Menengah Atas Muhammadiyah Boarding School Kota Bengkulu

5. Kemampuan peserta yang mengikuti pelatihan dalam kegiatan PkM ini masih perlu ditingkatkan

Beberapa saran yang dapat dikemukakan adalah:

1. Kegiatan ini berupa persiapan. Oleh sebab itu, perlu ditindaklanjuti dalam bentuk pelaksanaan program pada semester berikutnya.

2. Bahan ajar ini perlu direvisi untuk penggunaan di masa yang akan datang berupa elaborasi materi jenis konsep-konsep dan prosedur.

3. Kemampuan siswa yang mengikuti kegiatan PkM ini masih kurang. Oleh sebab itu, pada pelaksanaan GLS semester yang akan datang perlu diawai dengan kegiatan penyegaran materi, dan latihanlatihan.

\section{DAFTAR PUSTAKA}

Aliha Channel. 2016. Kampanye Duta Literasi SMP Negeri 1 Kota Bengkulu https://www.youtube.com/watch?v $=$ kkey 4 fcjs $2 \mathrm{~g}$. (diunduh 5 Juli 2017)

Aliha Channel. 2016. Budayakan Membaca, Pelajar SMAN 1 BS Rutin Membaca Serentak 15 Menit Sebelum Belajar. http://beritadelapan.com/budayaka n-membaca-pelajar-sman-1-bsrutin-membaca-serentak-15-menitbelajar/.(diunduh 5 Juli 2017).

Alwasilah A. Chaidar. Pokoknya Rekayasa Literasi. Bandung: PT Kiblat Buku Utama.
Antono, Billy. Gerakan Literasi Sekolah Dari Pucuk Hingga Akar Sebuah Refleksi. Jakarta: Direktorat Jenderal Pendidikan Dasar dan Menengah, Kemendikbud.

Direktorat Jenderal Pendidikan Dasar dan Menengah, Kemendikbud. tt. Buku Saku Gerakan Literasi Sekolah, Menumbuhkan Budaya Literasi di Sekolah. Jakarta: SATGAS Gerakan Literasi Sekolah.

Emzir dan Rohman. 2016. Teori dan Pengajaran Sastra. Jakarta: Raja Grafindo Persada.

Ismawati, Esti. 2013. Pengajaran Sastra. Yogyakarta: Penerbit Ombak.

Kemendikbud. 2016. Pedoman Mata Pelajaran SMA, MA, SMK, MAK, Mata Pelajaran Bahasa Indonesia. Jakarta: Kemendikbud.

Kemendikbud. 2017a. Buku Guru Bahasa Indonesia SMA/MA/SMK/MAK

Kelas $X$ Edisi Revisi. Jakarta:

Kementerian Pendidikan dan

Kebudayaan.

Kemendikbud. 2017b. Bahasa Indonesia SMA/MA/SMK/MAK Kelas X Edisi

Revisi. Jakarta: Kementerian

Pendidikan dan Kebudayaan.

Nurgiyantoro, Burhan 2015. Teori Pengkajian Fiksi (Yogyakarta: Gadjah Mada University Press.

Sari, Esti Swatika, dkk. 2013. Model Multi Literasi dalam Perkuliahan Bahasa dan Sastra Indonesia. LITERA Jurnal Penelitian Bahasa, Sastra, dan Pengajarannya, Vol 12, No 2, Oktober 2013, hlm 246-255. 
SMAN 5 Kota Bengkulu. 2016. Laporan Pelaksanaan Program Penumbuhan Budaya Literasi di SMA Tahun 2016. Provinsi Bengkulu.

Peraturan Menteri Pendidikan dan Kebudayaan RI Nomor 23 tahun 2015 tentang Penumbuhan Budi Pekerti.

Ramadansyah. 2012. Paham dan Terampil Berbahasa dan Bersastra Indonesia.Bandung: Dia Aksara Press.

Rokhmansyah, Alfian. 2014. Studi dan Pengkajian Sastra, Perkenalan Awal dengan Ilmu sastra. Yogyakarta:Graha Ilmu.

Suryanto, Edy, dkk. 2013. Model Pendidikan Model Pekerti Berbasis Cerita Anak untuk Penanaman Nilai Etis Spiritual. LITERA Jurnal Penelitian Bahasa, Sastra, dan Pengajarannya, Vol 12, No 2, Oktober 2013, hlm 235-245.

Waluyo, Herman J.. 1987. Teori dan Apresiasi Puisi. Jakarta: Penerbit Erlangga.

Wellek \& Warren. 1989. Teori Kesusastraan, terjemahan Melani Budianta. Jakarta: PT Gramedia.

Wiedarti, Pangesti, dkk.. 2016. Desain Induk Gerakan Literasi Sekolah. Jakarta: Direktorat Jenderal Pendidikan Dasar dan Menengah, Kemendikbud.
Wiyatmi. 2013. Representasi Sejarah Indonesia dalam Nove-novel Karya Ayu Utami. LITERA Jurnal Penelitian Bahasa, Sastra, dan Pengajarannya, Vol 12, No 2, Oktober 2013, hlm 209-223. 